B-1-05

\title{
百積指標によるヒトのトラッキング動作 評傮システム
}

\begin{tabular}{|c|c|}
\hline$\bigcirc$ 青山 & 貴 $\underset{\text { (伸奇玉工業大学) }}{\text { 小林 }}$ \\
\hline 田谷 & $\begin{array}{l}\text { 勝 夫 } \\
\text { (防衛医科大学石校) }\end{array}$ \\
\hline
\end{tabular}

【はじめに】我々は、人のトラッキング動 作をパーソナル・コンピュータで测定・解析 を行い、媨損賃患者、特に半侧視空間失認患 者の認知・行為能力を定量的に評価するアル コリズムを開発した。そこで、半侧視空間失 認患者のトラッキング動作の認知・行為能力 の客钼的な評価の指標として、視標と追従力 ーソルの偏差に注目した。それを、距離と方 向を合んだ偏差ベクトルと考え分析を試みて いる。また、視標を原点とし、原点移動した 偏差ベクトルによって構成される多角形分析 の有意性む合わせて検討を行った。

\section{【方法】㰾定システム：データ収集・表} 示装置として、一般に市販されているNEC PC -9801 シリーズと、追従の操作器としてマウ スを使用した。

邀定方法：トラッキング動作としては、 被験者に視標と追従カーソルを同時に表示す る追従型トラッキング動作とした。被呀者は 机に向かって楽な座位をとり、その前方約 1 mの距離に設置された本测定システムのCRT画 面上の移動視標を卓上のマウスを用いて追従 を行う。また测定にはいる前に被験者には、 マウスの操綂方法に習熟するために6 種類の 練習試行を行わせた。視標の軌跡は、単振動 運動であり、その移動速度である振動周波数 を0.014Hz〜0.229Hzまで、5段階に変化させ た。

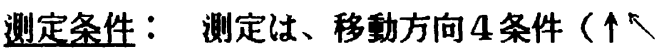
$\leftarrow \swarrow)$ 、周波数 5 条件 $(0.014,0.029,0.057$, $0.114,0.229 \mathrm{~Hz}$ )、計20条件につき行ったか、、 今回は、水平方向 (
$0.014,0.029,0.057 \mathrm{~Hz})$ のみの分析を行った。 测定対象：健常者12名（平均年龄65.8歳）、 腷損傷患者18名、うち半侧視空間失認（以下 USAと略する）を有する患者9名（平均年龄51 .8歳)、ない患者 9名 (平均年龄60.2歳)に ついて测定を行った。

分析方法： 視標とマウスカーソルの偏差を 距離と方向を含んだ偏差ベクトルと考え、以 下の 3 種類の分析を行った。

(1)視標とマウスカーソルの偏差の絶対值を1/ 4周期ごとに算出した。

(2)視標とマウスカーソルの偏差をとり、これ からベクトルを計算し、視標の移動方向ごと にマウスカーソルの遅れと進みの差をとった。 (3)視標を原点にして偏差ベクトルを二次元平 面上に表示し、そのベクトルで構成される外 接多角形を求め、形状と面積を求めた。

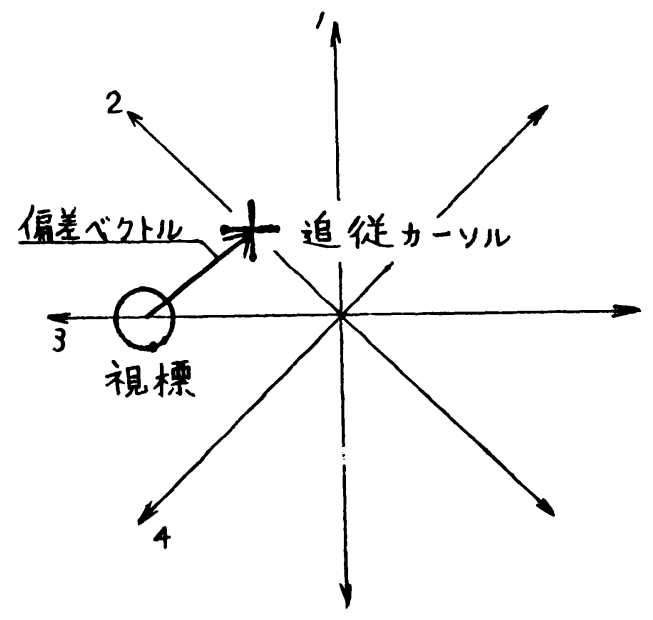

図1偏差ベクトル 
【测定結果】上記の(1)(2)について测定を 行ったが、ここでは紙面の都合上、(2)につい てのみ報告する。

次に(2)のベクトル分析では、健常者の場合、 测定開始から 1/4周期までは特に視標への追 従が良好であり、移動周波数が低いほどマウ スカーソルの軌道修正が頻繁に行い追従して いる様子が確認できる。しかむ、視標の移動 方向に対して垂直方向のずれはさほど認めら れなかった。また、USAが認められない患者 グループでは、初めの 1/4周期のとき、健常 者と同じ様に視標の回りで微調整を行いなが ら追従している。 $2 / 4$ 周期目から追従カーソ ルをステッブ状に運動させて追従を行ってい る。この現象は、視標の移動周波数加低いほ どその傾向が明確に確認できる。次に USAが 認めらる患者のグルーブでは、初めの $1 / 4$ 周 期は健常者グルーブと同じ追従動作を行うが、 2/4から 3/4周期のとき、即与、視標が左端 から右端に向かって移動するときは、ほぼ視 標と同じ運動で追従を行う。

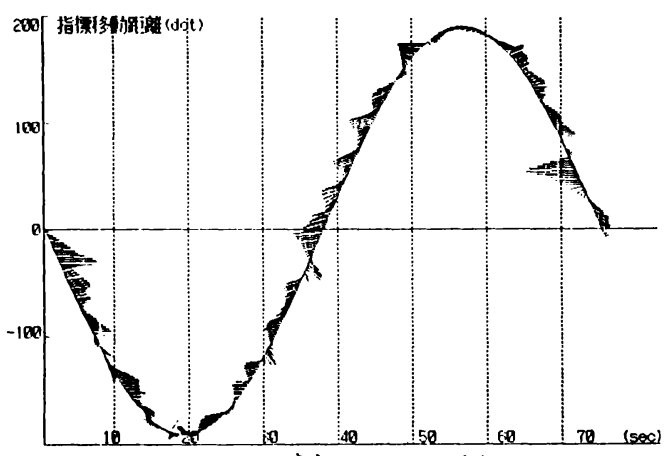

四2 USAが熟められは、们

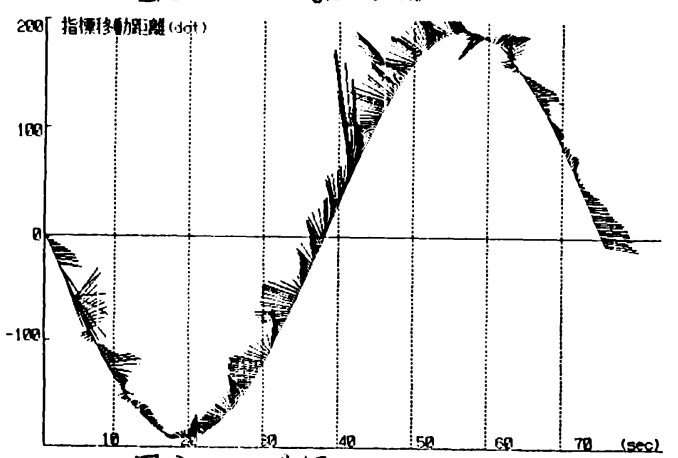

团了USAが热めらルい例

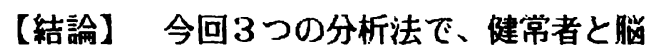
損稘障害者のトラッキング動作の分析を試み た。ここで報告した分析法での USAの有無の 差は、ベクトルの形状として現れている。即 ち、USAが認められるグループと USAが認め られないグループでは、視標の移動方向に対 して追従する仕方がちがうことが明らかにな つた。USAが認められないグループでは、視 標の位置加認知された後に、その位置に追従 カーソルを合わせるように制御を行っており、 それに対して、USAが認められるグルーブで は、視標の運動を予测し追従するフィードフ ォワード形になっている。

本稿のベクトル分析法によれば、追従カー ソルの動きを視覚的に表示することができる が、移動周波数が高くなるとベクトル同士が 重なってしまうため、ベクトルの絶対值をス ケールダウンするなどの表示方法を考える必 要がある。それに対して、外接多角形の分析 方法では、今のところ、一試行当りの多角形 を求めているか、これを一試行中の視標の移 動方向で処理した方がより具体的に USAの有 無を評価することができると思われる。

さらに、このトラッキング動作のモデルに よる解析を行う場合、フィードバック形とフ イードフォワード形を備えたモデルを構築し なければならないだろう。そして、この分析 法では、フィードバック形とフィードフォワ 一ド形を何らかの定量的指標により数值化す ることも今後の課題である。 